\title{
CARINĖS RUSIJOS KARO PRIEVOLE்S SĄRAŠAI IR NESĄRAŠINIAI DOKUMENTAI LIETUVOJE
}

\author{
Vilius Botyrius
}

Karo prievolès problematika vèl tampa aktuali nūdienai, kuriant Lietuvos kariuomenès infrastruktūrą. Kita vertus tai ne tik aukštosios politikos, bet ir aktuali tema daugumai piliečiu asmeniškai ypač vyriškajai jos pusei. Lietuvos visuomenè dar tebejunta skaudžias sovietinès karo prievolès pasekmes, nors kita vertus, iki šiol dar nèra isisąmonintos 120 metu trukusios carinès Rusijos karo prievolès pasekmès Lietuvai. Visuomenejje plačiau priimta tèra istorinè mintis, kad carinès Rusijos karo prievolè nemaža dalimi paskatino lietuvių emigraciją i JAV ir kitas šalis, pradedant 1874 metais ir iki pat prasidedant Pirmam pasauliniam karui 1914 m. Lietuviškosios istoriografijos šia tema tèra užuomazgos, dažnai prisiminimų lygio. „Karo archyvas" tarpukaryje spausdino V. Steponaičio straipsni, kuriame pasiremiant Rusijos oficialiais šaltiniais mėginta ịvertinti šauktinių, neatvykusių i šaukimo punktus, skaičiu pagal tautybes. Autorius teigia, kad 1908 metais pagal ši rodikli lietuviai užèmė tvirtą antrą vietą tarp visų imperijos tautų (23 nuošimčiai neatvykusių), atsilikdami tik nuo žydu šauktinių. Idomus ir A.Visocko straipsnis apie lietuvius tarnavusius carinès kariuomenès sudètyje Vidurinèje Azijoje ${ }^{2}$. Aneksijos atveju svetimuju primesta karo prievolè yra viena sunkiausių prievolių kraštui. Tačiau tūkstančiai ir tūkstančiai nežinomų likimų vis dar laukia kol bus pažadinti.

Ar jie buvo tik pasyvios aukos, ar istorikų neivertinti tautos egzodo herojai? Ieškantiems atsakymų praverstų Lietuvos archyvuose išlikusios Rusijos karo prievolès archyvinių dokumentų sisteminė apžvalga.

\footnotetext{
${ }^{1}$ Steponaitis V Lietuviai rusų kariuomenèje. Karo archyvas, T4, 1928.

${ }^{2}$ Visockas A. Kariai katalikai Rusijos imperijos armijoje Turkestane. Karo archyvas, T.15, 1998.
} 


\section{Karinè reforma}

Rusijos imperija įvedè savają karo prievolę Lietuvoje iš kart po aneksijos 1795 metais. Pirmiausiai ji palietè valstiečių ir miestiečiu luomus. Žydų luomas laikinai galèjo atsipirkti nuo karinès tarnybos specialiu mokesčiu, bet nuo $1827 \mathrm{~m}$. ir jie privalèjo atlikti prievolę ,natūra". Rekrūtų kvota vidutiniškai sudarydavo 5-8 vyrus nuo tūkstančio vyrų per metus, bet ívairavo, nežiūrint kokios buvo politinès aplinkybės imperijoje. Iki $1834 \mathrm{~m}$. rekrūto tarnyba truko 25 metus, vẻliau buvo trumpinama. Karo prievolininkų apskaitos sistemos iš esmès nebuvo. Jų surinkimas dažnai virsdavo gaudynėmis sodžiuose. Pralaimejjimas Krymo 1853-1856 m. kare Europos šaliu moderniom kariuomenėm paskatino Rusiją įvesti visuotinę karo prievolę. Jos pagrindai buvo nustatyti naujame Karo prievolès statute, caro pasirašytame 1874 sausio $1 \mathrm{~d}$ (senuoju stiliumi) ${ }^{3}$. Liberali reforma liete visus pasaulietinius luomus, nes dabar kiekvienas, tiek valstietis ar miestietis, tiek bajoras, buvo karo prievolininkas. Karo tarnyba buvo sutrumpinta iki 7 vèliau 5 metu. Nuo $1874 \mathrm{~m}$. visi šaukiamojo amžiaus, tai yra 20-ties metų, vyrai privalèjo traukti burtus, kam teks atlikti tikrają karinę tarnybą, o kas bus ịašytas i atsarginius. 19 ir 20 amžiu sandūroje Rusijos imperijoje kasmet buvo suskaičiuojama apie vieną milijoną šauktinių. Kariuomenei papildyti užteko 300 tūkstančių vyrų kasmet $^{4}$. Todèl ir Lietuvoje tarnauti kasmet turejo būti paimama apie pusę visų šauktinių. Nuo $1874 \mathrm{~m}$. kasmet naujokų kvotas vyriausybè nustatydavo proporcingai teritoriniu principu.

$1874 \mathrm{~m}$. îvedus visuotinę karo prievolę reikejjo sukurti ne tik karo prievolininkų, bet ir visų be išimties gyventojų, įskaitant moteris, apskaitos sistema. Nuo tada susiduriame su naujais Rusijos imperijos valstybinio aparato sukurtais karo prievolès sąrašais ir nesąrašiniais dokumentais. Visą karinès reformos eigą ir reformos šaltinius galima suskirstyti $\mathfrak{i}$ dvi dalis: pradinius, 1874 - 1876 metu, ir kasmetinius arba periodinius surašymus 1874 - 1915 m. Lietuvoje, kaip ir visoje Rusijos imperijoje. Pradini 1874 - 1876 metu etapa galima pavadinti tikru gyventojų apskaitos vajumi. Šiuo etapu buvo sudaryti pirminiai šeimų sąrašai, papildyti

3 Sbornik uzakonenij i rasporiaženij pravitelstva. St.Peterburgas, 1874.

${ }^{4}$ Bolšaja enciMopedia.St.Peterburgas.T.5.L.575. 
reviziniai surašymai ir surašyti žydai karo prievolininkai. Antram etapui galima priskirti jaunuoliu karinio prirašymo prie apylinkiu knygas (kniga dla zapisi pripisannych k prizivnym učastkam), kasmetinius šauktinių sąrašus (častnije prizivnije spiski), naujokų sąrašus (priemnaja rospis). Šiu gyventojų apskaitos šaltinių pavadinimai neatspindi viso jų turinio, nes be pačių karo prievolininkų juose randame ir jų šeimų narius. Nors karinė prievole tapo visuotine, tačiau ją organizuoti pavesta skirtingoms institucijoms vis dar luominiu principu. Dali šių sąrašų sudarè karo prievolès istaigos, ikurtos 1874 metais kiekvienoje apskrityje, kitus - jau seniau egzistavusios valstybinès ir luominès institucijos, tokios kaip miestų dūmos bei valsčiu valdybos ar miestiečių bendruomenès. Išimtį sudaro nuo Vilniaus apskrities atskirta Vilniaus miesto karo prievolès įstaiga, atskirai numatyta Karo prievolès statute. Deja, mes galime remtis daugiausia tik buvusių Vilniaus ir Kauno apskričiu istaigu archyvine medžiaga, nes Lietuvos archyvuose išliko beveik vien tik šių savivaldos isstaigų fondai.

\section{Prirašymo prie apylinkių sąrašai}

Karo prievolès pamatas - karo prievolininkų registracija - buvo numatytas Karo prievolès statuto \#96 punkte. Jaunuoliai nuo 16 iki 21 metu amžiaus, nepaisant luomo ir konfesijos, privalèjo kartą gyvenime paduoti pareiškimą registruotis (zajavlenije o pripiske k učastku) apskrities karo prievolès įstaigai (neapmokestintų luomų) arba miesto dūmai (apmokestintų luomų - vadinamosios revizinès sielos). Tai buvo galima padaryti asmeniškai, per tarpininką ar paštu. Pareiškimai buvo segami i bylas. Dèl to bajorų bei valdininkų ${ }^{5}$ ir nebajorų (krikščionių ir žydų) pareiškimai dažniausiai sudaro atskiras archyvų bylas. Tos pačios institucijos kiekvienam asmeniui išduodavo numeruotą prirašymo liudijimą (svidetelstvo o pripiske), išskyrus valstiečiu luomo asmenis, gyvenančius kaimo vietovese ${ }^{6}$. Tai suprantama, mat ši gyventoju kategorija buvo beveik visai sėsli. Prirašymo liudijimą buvo privaloma pateikti šaukimo metu, taip pat tuokiantis ir pradedant valstybès tarnyba. Pradiniu reformos metu liudijimą reikèjo gauti ne vèliau kaip iki gruodžio 31 dienos tų

\footnotetext{
${ }^{5}$ Vilniaus miesto privilegijuotų luomų šauktinių $1875 \mathrm{~m}$. prirašymo byla. Lietuvos Valstybès Istorijos archyvas (toliau LVIA), F.499.Ap.1.B.1592.

${ }^{6}$ Karo prievolès statuto punktas \#97,

60
} 
metuc, kuriais asmuo sulaukè 20-ties. Vèliau registruotis privalëjo 16mečiai. Jaunuoliai, gavę prirašymo liudijimą ir tapę karo prievolininkais, buvo registruojami i vadinamają prirašymo prie apylinkių knygą (knyga dlia zapisi pripisannych k prizyvnym učastkam). Šios knygos pavadinimas gana klaidinantis. Visu pirma tai buvo viena bendra knyga visoms šaukimo apylinkėms, esančioms apskrityje. Pavadinime apylinkių daugiskaita pavartota tik todèl, kad knygos klausimyne dažniausiai yra nurodomi ir šauktiniu apylinkių numeriai, o ne todèl, kad knygas sudare kokios nors apylinkių institucijos. Karo prievolininkų šaukimo apylinkès neturèjo savų valdininku aparato. Tiesiog rudeni, kai pradeddavo veikti šaukimo punktas, 10-čiai dienu čia buvo komandiruojami apskrities karo prievolès įstaigos valdininkai. Šauktinis prie atitinkamos apylinkès nesigilinant buvo prirašomas pagal gyvenamają vietą.

Iš jaunuolių pareiškimų bylų bei prirašymo knygų anketos galima sužinoti asmens duomenis, luomą, gimimo data, konfesija, raštingumo lygi, užsièmimą ar verslą, prirašymo liudijimo išdavimo datą ir jo numeri, gyvenamają vietą arba bent šaukimo apylinkę ir metus, kuriais karo prievolininkas buvo įtrauktas į šauktiniu sąrašą. Žinoma, jei valdininkai, pildę anketą, buvo pareigingi, o taip būdavo toli gražu ne visada. Kita vertus, ne visada 19 amžiuje aplinkybès leido surinkti tokias žinias. Nuoseklumu carinès Rusijos ịstatymu kūrèjai, atrodo, nepasižymėjo. Viena iš vertingiausiu tyrinètojams nuostatu yra reikalavimas, kad paduodantys pareiškimus jaunuoliai pateiktų gimimo metrikų nuorašą. Tačiau kilę sunkumai privertẻ miestų dūmas ir valsčiu valdybas išduoti laikinus prirašymo liudijimus ir be metrikų nuorašų ar iš vis nenurodant karo prievolininko amžiaus. Tai ypač buvo aktualu 1874-siais, pirmais reformos metais. Tais metais jaunuoliai prie karinès prievolès apylinkių buvo prirašomi ir šauktiniu sąrašai buvo sudaromi vienu metu, todèl iš dalies neteko prasmès. Apie karo prievolès reformą buvo pranešama bažnyčiose, maldos namuose bei per skelbimus?. Kauno dūmą siekè karo prievolininku prirašymą pabaigti iki balandžio $15 d$.। bet jis užtruko iki rudeninio šaukimo pradžios, ir vargu ar buvo užbaigtas galutinai. Ypatingujų reikalu valdininkas, stebėjęs karo prievolès reformos igyvendinimą Vilniaus gu-

\footnotetext{
${ }^{7}$ Biržų policijos pareigūno 18740329 raportas. Kauno Apygardos archyvas (toliau - KAA), F.61.Ap.2.B.5337, L.158.

${ }^{\mathrm{s}}$ Kauno apskrities šauktinių 1874 m. prirašymo pareiškimai. KAA, F.61Ap.2.B.5218, L.37108.
} 
bernijoje, mini, kad tik apie 50 šauktiniu iš Vilniaus miesto $1874 \mathrm{~m}$. rugsėjo mènesi turèjo prirašymo liudijimus*. Pirmais reformos metais pagal Karo prievolès statutą privalèjo būti surašyti tik visi dvidešimtmečiai. Jaunesni galèjo dar atidèti šią procedūrą kitiems metams, ir čia būta daug nesusipratimų ir mažai patirties $i^{\circ}$.

\section{Šauktinių sąrašai}

Šauktinių sąrašai po 1874 metų tapo pagrindine informacijos baze organizuojant kasmetinę kariuomenès naujoku atranką. Tačiau 1874 m. statutas neduoda aiškaus apibrèžimo, kas yra tas šauktiniu sąrašas. Kaip archyvo byla tai tèra didelio formato dažniausiai spausdinta anketa, susidedanti iš 18 skyrių klausimyno, kuris plačiai nusako karo prievolininko ar net jo šeimos gyvenimo charakteristiką. Vienas vertingiausiu yra punktas apie šauktinio, pretenduojančio i lengvatas, šeimos nariu sudèti. O tokių buvo nemažai. Metų laikotarpiu nuo pirmo iki dešimto anketos skyrius (miestiečiams ir valstiečiams) užpildydavo savivaldos institucijos, o nuo 11 iki 18 - apskričiu karo prievolès įstaigos. Tik metų pabaigoje galutinai sutvarkoma anketa, metu laikotarpiu tačiau, ji ivvairiu institucijų buvo įvardijama tuo pačiu šauktinių sąrašo pavadinimu. Todèl simboliška, kad dažnai (bent 8-ajame dešimtmetyje) ši anketa spausdinta be titulinio pavadinimo.

Vienintelis statute minimas tikslus šauktinių sąrašo kriterijus yra amžiaus cenzas. Kasmet turejo būti suregistruojami visi jaunuoliai, kuriems praejjusiais metais sukako 20 metu. Toliau statute išdèstomas procedūrų, kaip teisingai nustatyti karo prievolininkų amžių, sąrašas, ir tam skiriami beveik visi kiti statuto skyriaus punktai. Todèl šauktinių sąrašai visiškai atitinka savo pavadinimą tik kiekvienų metų rudeni, prieš pat šauktiniams traukiant burtus. Amžiaus nustatymas 19 šimtmetyje buvo opi problema, sunkiai suvokiama dabartiniame visuotinès pasportizacijos amžiuje. Iki šaukimo pradžios taip ir nepavykdavo sudaryti bendro šauktinių sąrašo. Visų pirma dèl tos pačios amžiaus problemos. Para-

\footnotetext{
${ }^{9}$ Ypatingujų reikalų valdininko P.Voicekovskio 18740725 raportas Vilniaus gubernatoriui. 
lèliai būdavo sudaromos dvi formos: pagrindinis sąrašas šauktinių, kurių amžiumi neabejojama, ir specialus sąrašas šauktinių, kurių amžių turejjo nustatyti speciali komisija jau rudens šaukimo metu. I pastaraji, laimei ar nelaimei, dažniausiai pakliūdavo šauktiniai žydai. Antra, nors karo prievolè tapo visuotine, bet ji buvo vykdoma luominio skirstymo pagrindu ir skirtingu institucijų. Bajoru, valdininkų ir kitų neapmokestintų pagalvès mokesčiu luomu šauktiniu sąrašus sudarydavo nuo pat pradžiu tik karo prievolès istaigos. Apmokestintų luomų (miestiečių, valstiečiu ir kitų) sąrašus pradiniame etape sausio-gegužès mėnesiais buvo pavesta sudaryti miestu durnoms ir valsčiu valdyboms. Bet kadangi realiai juos sudarydavo skirtingų konfesiniu bendruomeniu deputatai, tai buvo paskiru bendruomeniu luominiai sąrašai (častnije prizivnije spiski). Tik antrame etape, nuo birželio mėnesio, apskričiu karo prievolès įstaigos sugrupuodavo ịvairių luomų ir bendruomenių sąrašus i apylinkinius šauktinių sąrašus ir tik tam, kad, atsižvelgiant i bendrą šauktiniu skaičiu apylinkèse, gubernijos karo prievolès istaiga paskirstytu naujoku kvotas kiekvienai apylinkei. Keliapakopę surašymo eigą iš esmès lèmè skirtingi šaltiniai, kurių pagrindu buvo nustatomas vyrų amžius ir sudaromi 20 -mečiu sąrašai. Karo prievolès statutas mini tokius šaltinius šauktinių sąrašams sudaryti: a) metrikų išrašus, b) revizinius sąrašus, c) prirašymo liudijimus, d) asmeninius pareiškimus, e) numatomus ateityje sudaryti šeimų sąrašus. Suvalkų gubernijoje kaip ir visoje Lenkijos Karalysteje tokiu pagrindu buvo gyventojų knygos". Bajorų bei valdininkų šauktiniams toks šaltinis galèjo būti tik metrikų išrašai, nes šie luomai, kaip neapmokestinti pagalvès mokesčiu luomai, ị revizinius sąrašus nebuvo itraukiami. Be to, metrikų nuorašą reikejo pateikti ir personalinès registracijos atveju. Miestiečiu, valstiečių, žydų ir kitu luomų, apmokestintu pagalvès mokesčiu, šauktinių sąrašai buvo sudaromi remiantis tiek metrikomis, tiek reviziniais ar šeimu sąrašais. Natūralu, kad turint du šaltinius, pasitaikydavo atvejų, kai duomenys nesutapdavo. Ypač amžius, o žydu - ir vardai. Neretai viename iš šaltinių asmuo išvis nebūdavo irašytas. Galima būtų suprasti toki dubliuotą ir sudètingą šauktiniu sąrašų sudarymo būdą kaip apsidraudimą nuo klaidų ar sunkumų vieno iš šaltiniu prapulties, tarkim, stichinès nelaimès, atveju. Tačiau vieno šaltinio pirmenybè kito atžvilgiu, susieta su

\footnotetext{
11 žr. Karo prievolès statuto punktą \#105, 106. Sbornik uzakonenij i rasporiaženij pravitelstva. St.Peterburgas, 1874
} 
šauktinio išpažistama religija, rodo apie diskriminacinę carinès Rusijos politiką „kitatikių" atžvilgiu. Sudarant šauktinių sąrašus ir nustatant jų amžių, kai revizinių sąrašų ir metrikų duomenys nesutapdavo, krikščionims metriku duomenys buvo svarbesni už revizinių sąrašų duomenis, o nekrikščionims (žydams, mahometonams) - atvirkščiai. Kita vertus, dar kartą buvo patvirtintas liūdnai pagarsèjęs carizmo biurokratinis principas - nèra to dokumento, kuriam patvirtinti nereikètu kito dokumento, nes kiekvienas i̊statymo punktas, išaiškinantis teisingą amžiaus nustatymo tvarką, galèjo būti paneigtas kitu punktu. Galiausiai kokios nors abejonès ar skundo (pagal statuto punktą \#111 apskųsti dèl neteisingo šauktinio amžiaus galèjo bet kas) atveju lemiamą sprendimą priimdavo karo prievolès istaiga, šauktinio amžių nustatydama „iš akies", pagal jo išorini fizini subrendima. Nèra ko kalbèti, kad tai buvo savavališki sprendimai, objektyviai sudarę sąlygas pasipelnyti.

Taigi šauktinių anketose jų amžius turèjo būti nurodomas tiek pagal revizinių sąrašų duomenis, tiek pagal metrikas. Todèl miestų dūmos bei valsčių valdybos turejjo organizuoti ir revizinių sąrašų (nuo 1875-1876 metų juos keičia šeimų sąrašai) peržiūrą, ir metrikų išrašų sudarymą. 1874 metais abu darbai pradèti vienu metu, atsižvelgiant ị vidaus reikalų ministro $1874 \mathrm{~m}$. sausio $25 \mathrm{~d}$. aplinkraštị". Rašte gubernatoriams buvo nurodoma tuoj pat, $1874 \mathrm{~m}$. sausio-vasario mènesiais užbaigus paskutini imperijos rekrūtų èmimą, sudaryti karo prievolès šauktinių sąrašus ir baigti iki balandžio 1 dienos. Taigi šauktinių sąrašams sudaryti paskirta pusantro mėnesio. 1874 metų šauktinių sąrašų Lietuvoje sudarymas atskleidžia tiek visų paskesnių tokių surašymų dèsningumus, tiek svarbias 1874 metų gyventojų apskaitos bumo aplinkybes.

\section{Reviziniai išrašai}

Tokio pavadinimo užduotis nebuvo numatyta Karo prievolès statute". Straipsnyje "revizinių išrašų" pavadinimu vadinama pirminè informacija, kuri buvo pradžiu pradžia ir kuria buvo pradedama pildyti

\footnotetext{
${ }^{12}$ Vidaus reikalu ministro 18740125 aplinkraštis Nr.1, LVIA, F.937.Ap.2.B.3639, L.1.

${ }^{13}$ Bet asmenys, pildantys šauktinių anketas, galëjo sudaryti išrašus iš vadinamujų revizinių sielų sąrašo, tai yra pagalvės mokesčio mokètojų rejestro, kaip grynai darbinius sąrašus.
} 
šauktinių anketos, tai yra pavardè, vardas, tèvavardis, šeimos eilès numeris reviziniame sąraše, ir, žinoma, šauktinio amžius. Šiai informacijai gauti naudotas paprastas principas. Kasmet iš revizinių sąrašų buvo atrenkami irašai apie 20-ties metu jaunuolius. Reviziniai surašymai Lietuvoje buvo periodiškai kartojami nuo pat Rusijos aneksijos pradžios 1795 m. Paskutinis revizinis surašymas atliktas 1858 metais. Taigi $1874 \mathrm{~m}$. šauktiniais tapo tie jaunuoliai, kurie $1858 \mathrm{~m}$. reviziniame sąraše įrašyti, kaip esantys penkerių metų amžiaus, atitinkamai 1875 metais - ketverių, 1876 - trejų. Atranką iš $1858 \mathrm{~m}$. revizinių sąrašu turèjo atliko miestiečiu bendruomenių išrinkti, taip vadinami, deputatai - tiek krikščionių, tiek žydų, nors Karo prievolès statutas pavedè šauktinių sąrašus sudaryti tiesiogiai miestų durnoms ir valsčiu valdyboms". Vilniaus miesto krikščioniu bendruomenè 1874 metais dèl to nesèkmingai protestavo". Savivaldybès sau pasiliko tik sprendžiamaji vaidmeni ir prižiūrèjo, ar teisingai bendruomenès pildo šauktinių anketas.

1874 metais Vilniaus dūmą pasitelkus policiją reikalavo iš visu jai pavaldžių bendruomenių ${ }^{\wedge}$ sudaryti ir pristatyti šauktinių sąrašus i dūmą iki kovo 17 dienos". Vilniaus miestas vienintelis Lietuvoje, kaip ir kiti keliolika didžiausių Rusijos imperijos miestų, gavo atskira nuo Vilniaus apskrities karo prievolès istaigą ir taip sudare ypatinga grynai miestiečiu šaukimo apylinkę. Tačiau šiai miesto karo prievolès ịstaigai pavaldūs tapo ir visi Vilniaus apskrities miestelių žydai dèl jų bendruomenių pavaldumo Vilniaus dūmai. Vilniaus miesto žydų bendruomenė šauktinių sąrašų tuščias anketas gavo tik kovo 11 dienai, o jau kovo 20-tą, pasak policijos pareigūno pranešimo^, dauguma Vilniaus apskrities žydų ben-

\footnotetext{
" žr. Vilniaus miesto Galvos 18740211 nutarimas. LVIA, F.937. Ap2. B.3639, L.1-2.

${ }^{15}$ Vilniaus miesto krikščionių bendruomenès deputatų 18740327 raštas Vilniaus 3-ios poli cijos nuovados viršininkui. LVIA, F.937. Ap.2. B.3639, L.88.

16 žr. tokių bendruomenių sąrašą toliau straipsnyje.

" Vilniaus miesto dūmos 18740314 nutarimas \#20. LVIA F.937. Ap.2. B.3639, L. 14

${ }^{18}$ Vilniaus miesto dūmos 18740309 kvietimas atvykti pasiimti anketas. LVIA, F.937. Ap.2. B.3639, L. 15 .

19 Vilniaus apskrities policijos pareigūno 18740320 pranešimas Vilniaus miesto dūmai. LVIA, F.937. Ap.2. B.3639, L.47.
} 
druomenių pristatė šauktinių sąrašus i Vilniaus dūmą. Iš tiesų tai buvo dar tik pusiau užpildytos šauktiniu anketos. Negausioms Vilniaus apskrities miesteliu žydų bendruomenėms nebuvo didelio vargo per savaitę atrinkti iš revizinių sąrašu irašus apie dvidešimtmečius, nes šaukiamojo amžiaus jaunuolių tose žydų bendruomenėse rasta tik keletas ar keliolika: Antakalnyje $^{20}$ - 6, Naujamiestyje -1, Šnipiškèse - 6, Bagaslaviškyje - 5, Čiobiškyje - 4, Gelvonuose - 12, Michališkyje - 8, Molètuose - 6, Musninkuose - 3, Paberžèje - 13, Širvintose - 4. Didesnès bendruomenès nesuspejjo to padaryti iki nustatyto termino. Vilniaus miesto krikščionių bendruomenè 297 jaunuoliu sąrašą atsiunte tik balandžio 18 dieną, Vilniaus miesto žydų bendruomenė 140 jaunuolių sąrašą pristatė per du kartus balandžio 9 ir 23 dienomis. Paskutinè buvo Vilniaus garbès piliečių bendruomenè, 9 jaunuolių sąrašą i Vilniaus dūmą pristačiusi balandžio 24 dieną*. Gaila, kad negalime šių duomenų palyginti su valsčių valdybų surinkta šauktinių statistika, nes Vilniaus apskrities karo prievolès įstaigos fondas neišliko. Nežinoma bajorų ir valdininkų šauktinių statistika, kurią rinko tik miesto karinès prievolès įstaiga. Žinoma, šie skaičiai skyrèsi nuo galutinių metinių šauktinių skaičiaus.

Užpildyti šauktinių anketas pagal išrašus iš revizinių sąrašų buvo palyginti nesunku, nes revizinių sąrašu buvo saugomi keli egzemplioriai, kuriu po vieną turejjo ir savivaldybès, ir konfesinių bendruomenių deputatai. Daug sunkiau sekèsi surinkti reikiamas žinias apie karo prievolininkus ir jų amžių iš metrikų knygų, kaip reikalavostatutas ir vienas šauktinių anketos paragrafas. Dèl to 1874 metais nuo balandžio 15 iki gegužès 1 d., Vilniaus dūmą savo pastate iškabino, kaip numate Karo prievolès statutas - viešai piliečiams susipažinti ir klaidoms apskusti, - preliminarius šauktinių sąrašus, ne tik kad nesutikrintus su metrikų išrašais ${ }^{22}$, bet ir nesulaukusi visų revizinių išrašų. Iš ypatingujų reikalų valdininko 1874 m. liepos 25 d. raporto Vilniaus gubernatoriui aiškejja, kad šaukti-

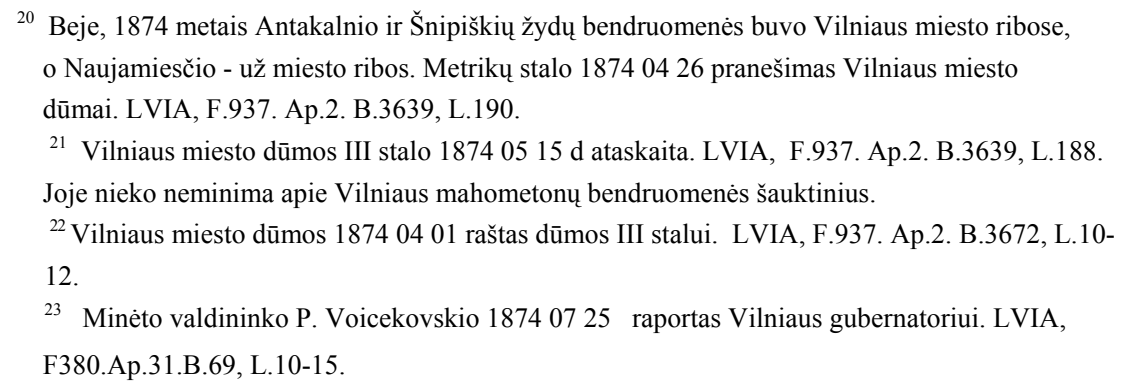

66 
nių sąrašas, bent jau Vilniaus mieste, 1874 metais buvo sudaromas „išimtinai perrašant" revizinio surašymo duomenis ${ }^{23}$.

Reikia manyti, kad bent jau mažesnių miestų ir valsčiu valdybos, kur gyventojų buvo mažiau, galejo paskelbti gyventojams ir išsamesnius šauktinių sąrašus.

\section{Metrikų išrašai}

Daryti metrikų išrašus buvo numatyta Karo prievolès statuto punktuose \#106 ir \#107. Tai buvo dar vienas šaltinis dvidešimtmečių karo prievolininkų sąrašams sudaryti. Metrikų išrašų anketose yra pateikiami karo prievolininko asmens tapatybès duomenys (nesantuokoje gimusiuju - motinos vardas), tiksli gimimo data ir vieta pagal parapijas, luomas arba amatas, kartais mirties data, jei berniukas mirè nesulaukęs 20-ties metu. Kadangi krikščioniškų konfesijų metrikų knygos buvo saugomos ne valstybinėse, o konfesinèse institucijose, metrikų išrašus sudaryti pasirodė sudètingiau nei išrašus iš revizinių sąrašu. Parapijų vadovai pirmais metais buvo nepasiruošę jiems užkrautoms valstybinèms pareigoms, todèl šiame darbe būta daug sumaišties.

Didžiausią problemą kèlè būtina keleriopa metrikų išrašų separacija, kurią turèjo atlikti parapijų valdytojai. Pirmiausia reikèjo skirstyti pagal luomą adresata, nes bajoru, valdininkų, karininkų ir kitu neapmokestintu pagalvès mokesčiu luomų karo prievolininkų metrikų išrašus tiesiogiai rinko apskričiu (ir Vilniaus miesto) karinès prievolès i̇staigos, o miestiečių, valstiečiu ir kitų apmokestintų luomų - atitinkamos luomu institucijos. Antra problema buvo nesutapimas bažnytinès ir valstybinès administracijos ribų. Klebonai, nežinodami, kurie jo parapijos kaimai kokiam valsčiui priklauso, nežinojo, kurio valsčiaus valdybai išsiųsti valstiečių šauktinių metrikų išrašus. Tarkim, Lavoriškių parapijos klebonas, 1875 m. sausi išsiuntęs metrikų išrašus Mickūnų valsčiaus valdybai, buvo apskustas Bistryčios valsčiaus valdybos, laukusios iš jo taip pat tokio išrašo $^{24}$. Luominis principas, rūšiuojant metriku išrašus, buvo viršesnis už gyvenamosios vietos geografini administracini kriterijų. Trečia problema buvo susijusi su gyventojų vidine migracija, natūraliu gyventojų judèji-

\footnotetext{
${ }^{24}$ Vilniaus Romos Katalikų dvasinès konsistorijos 18750621 laiškas Vilniaus gubernijos karo prievolès įstaigai. LVIA, F.498. Ap.1. B.292, L.24.
} 
mu. Dvasininkai privalèjo peržiūrèti ir mirčiu registracijos metrikų knygas ir pažymèti šauktinių sąraše mirusius jaunuolius. Karo prievolininkui palikus gimtają parapiją jos valdytojui buvo sunku patikrinti galimą jaunuolio mirties faktą. Taip metrikų išrašuose buvo registruojamos ir „mirusios sielos" tiesiogine ir perkeltine prasme. Susidaro įspūdis, kad valdininkams mirtis buvo pats neitikimiausias dalykas, ir jie vis mègino pašaukti mirusiuosius prie ginklo, nerasdami metrikose įrašų apie karo prievolininko mirtị bei nenoredami tikèti liudininkais ${ }^{25}$. Dèl gyventojų migracijos neišvengiami pasidare metriku išrašų mainai. Parapijų vadovai vis dažniau metrikų išrašus siunte in corpore artimiausiai šauktinių sąrašus sudarančiai institucijai, kratydamiesi metrikų išrašų skirstymo. Pavyzdžiui, Vilniaus apskrities Bistryčios valsčiaus valdyba gautuose iš parapijų 1875 metų metrikų išrašuose atrado keletą miestiečiu luomo šauktinių ir perdavė jų sąrašą Vilniaus dūmai ${ }^{26}$.

Pagal statutą metrikų išrašai kiekvienais metais turejo būti sudaryti iki sausio 15 dienos. Bet dèl pirmujų reformos metų ypatingų aplinkybių Vilniaus dūmą tik vasario 11 dieną nutare prašyti visų konfesijų hierarchu pristatyti šauktinių metrikų išrašus ${ }^{2}$ ? Ir tik kovo viduryje juos pradejo gauti iš krikščionišku konfesijų parapijų ${ }^{28} .1874$ metais buvo sudaromi jaunuolių, gimusių 1853 metais, metrikų išrašai bei ieškoma galimujų mirčių patvirtinimo 1853-1873 metu metrikose ${ }^{2 *}$. Vilniaus dūma metriku išrašu gavo tiek iš Vilniaus miesto ir apskrities parapiju, tiek iš parapijų ${ }^{30}$, esančiu kitose gubernijose, jei ten buvo surašyta Vilniaus miestiečio gimimo metrika. Tai yra luominis statusas buvo paveldimas iš savo tèvų, neatsižvelgiant i gimimo vietą.

Ypač daug buvo persiunčiama išrašų iš žydų metrikų, nes tai buvo pats nesèsliausias luomas. Čia carinès biurokratijos aparatas turejjo pasiduoti. Caras $1876 \mathrm{~m}$. vasario $3 \mathrm{~d}$. (senuoju stiliumi) potvarkiu leido nuo

\footnotetext{
${ }^{25}$ Vidaus reikalu ministro 18740712 aplinkraštis \#56. KAA, F.61. Ap.2. B.5337, L.188.

${ }^{26}$ Bistryčios valsčiaus valdybos 18750408 pranešimas Vilniaus miesto dūmai. LVIA, F.499. 
1877 metų žydams karo prievolę atlikti pagal faktišką gyvenamają vieta, o ne pagal registraciją prie „revizinės" bendruomenės*. Kitaip nei krikščionių, žydu metrikos nuo $1854 \mathrm{~m}$. buvo pradètos saugoti apskrities miestų durnose ${ }^{32}$. Todèl žydų metrikų išrašus turèjo sudaryti pačių miestų dūmų metrikų stalai ${ }^{33}$. Bet 1874 metais reikèjo išrašu iš 1853 metų žydu gimimo knygų, kurių durnose nebuvo. Jų teko ieškoti policijos istaigose arba sinagogose. Ne visų bendruomenių buvo rastos. Kita vertus, ne visos bendruomenès 1853 metais buvo savarankiškos ir turejo savas metriku knygas. Pavyzdžiui, Vilniaus apskrities miestelių žydų bendruomenès tik nuo 1854 metu turèjo atskiras knygas ${ }^{34}$. Todèl pasirodè, kad kartais neimanoma patikrinti žydų šauktinių sąrašų, remiantis gimimo ir mirties metrikų knygomis. Vilniaus mieste žydų metrikų knygos buvo rastos, ir šauktiniu sąrašu patikrinimo darbas miesto galvos nurodymu turèjo būti pradètas $1874 \mathrm{~m}$. balandžio $1 \mathrm{~d}^{35}$

Tačiau cariniai valdininkai nenorejo tikèti ir žydų revizinių sąrašų duomenimis, nors pagal įstatymą revizinių surašymų duomenys turèjo pirmumą prieš žydų metrikas. Menkiausių abejonių dèl revizinių duomenu atveju žydams buvo taikomas Karo prievolès statuto straipsnis dèl amžiaus nustatymo pagal išorini subrendimą ${ }^{36}$. Galiausiai carinè vyriausybė nutare 1874 metų rudeni atlikti visuotini žydų vyrų surašymą visoje imperijoje. Atrodo, kad Vidaus reikalų ministerijos nutarimas*, leidžiantis 1874 metais nustatyti karo prievolinkų amžių vien iš revizinių duomenų, žydams nebuvo taikomas.

Turint šauktinių pirmini sąrašą, sudarytą pagal revizinių sąrašų duomenis, ir metrikų išrašus, reikejo atlikti abiejų šaltinių šauktinių kryžmini sutikrinimą. Jei neatsirasdavo asmens tapatybès problemų, tereikedavo iš metrikų išrašų i anketas perrašyti tikslią šauktinio gimimo datą. Jei

\footnotetext{
${ }^{32}$ Metų pabaigoje rabinas žydų metrikas turèjo perduoti miestų savivaldybėms saugoti. Kauno gubernatoriaus 18740402 aplinkraštis \#2919. KAA, F.61. Ap.2. B.5337, L.51.

33 Vilniaus miesto Galvos 18740228 nutarimas. LVIA, F.937.Ap.2.B.3639, L. 11 ir Vidaus reikalų ministro 18740206 aplinkraštis \#3. LVIA, F.498. Ap.1. B.2, L.5.

34 Visos anksčiau išvardintos bendruomenès, kurios $1874 \mathrm{~m}$. pristatė šauktinių sąrašus Vilniaus dūmai, Min. raštas. LVIA, F.937. Ap.2. B.3672, L. 10.

${ }^{35}$ Rusų Geografijos draugijos Šiaurès Vakarų skyriaus 18741022 raštas Vilniaus miesto dūmai. LVIA, F.937. Ap.2. B.3672, L. 13.

${ }^{36}$ Vilniaus gubernatoriaus 18750418 aplinkraštis. LVIA, F.499. Ap.1. B, L.49.

${ }^{37}$ Min. aplinkraštis, LVIA F.498. Ap.1. B.2, L.5.
} 
šauktinis buvo „matyti" tik metrikų išrašuose, iš jo reikalauta įsirašyti $\mathfrak{i}$ revizinius sąrašus. Iš šiu asmeninių papildomų revizinių lapų buvo gaunamos kitos žinios šauktinio anketai užpildyti. Pirmuose išlikusiuose 1877 metų Vilniaus miestiečių šauktinių sąrašuose nelengva ižvelgti jų sudarymo etapus. Pirmi 39 šauktiniai iš bendro maždaug 700 krikščionių bendruomenès pagrindinio sąrašo greičiausiai yra itraukti naudojantis prirašymo knygomis ar prirašymo liudijimais. Daugumos iš šių šauktinių nurodyta tiksli gimimo diena. Toliau aiškiai išsiskiria sąrašo dalis, kurios pagrindas buvo reviziniai sąrašai, beje, turinti ir darbinę antraštę. Šioje dalyje, irašyti 389 šauktiniai. Jų tiksli gimimo data nurodyta labai retai, o amžius nurodytas remiantis reviziniais surašymais, pradedant nuo pagrindiniu, vykusiu 1858 metais, ir baigiant paskesniais, papildomais surašymais, iki pat 1877 metų. Dar toliau yra keliasdešimties vyrų papildomas, 1877 metu surašymas, bei kelių šauktinių sąrašai, sudaryti 9-ajame dešimtmetyje! Tai reikštų, kad šauktiniai, kuriems šaukimas dèl įvairiu priežasčių buvo atidètas, nebuvo perkeliami i kitų metų sąrašus, bet likdavo tik pirmame, todèl šauktinių sąrašus galime pavadinti tęstiniais). Paskutiniu 1877 metų sąrašo šauktinių buvo 1886 metais i ji irašytas 30 -metis kalinys ${ }^{38}$.

Reformai įsibėgèjus, šauktinių sąrašų sudedamujų dalių sutikrinimas daugiau ar mažiau turèjo būti spèjamas užbaigti iki balandžio 15 dienos, datos, kai pagal statutą reikèjo šauktinių sąrašus iškabinti viešai ar paskelbti bendruomenių sueigose. Kitaip netenka prasmès Statuto reikalavimas, kad karo prievolininkai patys praneštų, pastebèję esą sąraše praleisti. Priešingu atveju šauktiniams grasinta, kad jie bus paimti i kariuomenès naujokus be teisès į burtus. Miestų dūmos ir valsčių valdybos vèl prisièmé tik kontrolès funkciją, visą sutikrinimo darbą pavesdamos bendruomenėms. Pastarosios, bent Vilniuje, gaudavo tik metrikų išrašu nuorašus. Originalą savivaldybės pasilikdavo sau. 1874 metais Vilniaus dūmą toki metrikų išrašų dublikatą Vilniaus miestiečių krikščionių deputatams išsiuntė gegužès 15 dieną, o žydų - gegužès 4-ają, nurodydama per septynias dienas sudaryti ir atsiųsti dūmai papildomą šauktinių sąrašą ${ }^{3 *}$. Gegužès 21 dieną jau visų pavaldžių Vilniaus dūmai bendruomenių šauktiniu sąrašai, kad ir kokie jie buvo, Vilniaus dūmos buvo perduoti miesto Karo prievolès istaigai ${ }^{40}$. Tačiau miestų dūmos ir valsčių valdybos

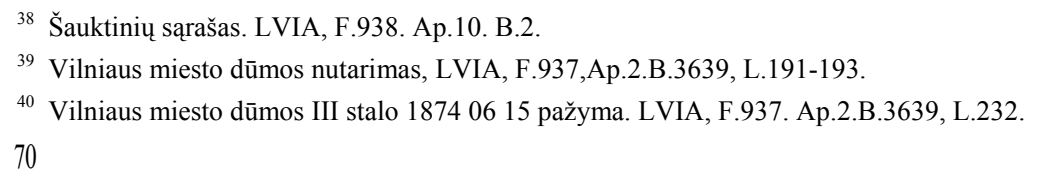


galëjo sąrašus papildyti iki liepos 1 dienos. Vilniaus žydų bendruomenė po beveik dviejų mènesių raportavo Vilniaus dūmai, kad, vadovaudamasi 1853 metu gimimo metrikų išrašais, radusi nemažą skaičiu jaunuolių, neirašytu i revizinius sąrašus. Bet tuo problema nebuvo išspręsta. Pasirodo, bendruomenè negalinti tokiu neregistruotu ,sielų" itraukti i šauktiniu sąraša, nes reikia, kad tie jaunuoliai pateiktų savo revizinius lapus«. Noredama paskatinti šauktinius nesislapstyti, caro vyriausybė atleido nuo baudu visus asmenis, pateiksiančius tokius lapus. Asmuo, neitrauktas i revizinius sąrašus, tai yra nepriklausantis jokiai luominei bendruomenei buvo „nelegalas". Bažnytinès metrikacijos neužteko asmens tapatybei nustatyti. Be to, pasirode, kad labai dažnai metrikų knygose prie naujagimiu nei ju luomas, nei bendruomenè nebuvo pažymèti. Teko tokiu ,niekieno" šauktiniu sąrašus skelbti „Gubernijos žiniose", o jiems neatsišaukus, irašyti juos ị šauktinių sąrašus bendruomeniu pagal gimimo vietą. Galu gale šauktinių sąrašai turejo iki liepos 1 dienos atsidurti apskričių karinès prievolès istaigose.

\section{Šaukimo apylinkès}

Karo prievolès ịstaiga surinkdavo paskirų bendruomenių šauktinių sąrašus iš visos apskrities. Iki prasidedant rudens šaukimui, šios istaigos daugiausiai užsiëmè praleistų karo prievolininku paieška. Šauktinių anketos klausimyno skyriai Nr.11-18 iš esmès buvo pildomi jau šaukimo metu: karo prievolès įstaigos pažymėdavo šauktinius, pretenduojančius į lengvatas, irašydavo medikų komisijos išvadas, pažymėdavo šauktinius, paimtus i kariuomenę naujokais, ir taip toliau. Bet jau liepos 1 dieną ši isstaiga turèjo pranešti viršesnei gubernijos karo prievolès istaigai tiek bendra visos apskrities šauktinių skaičiu, tiek jų skaičiu pagal šaukimo apylinkes. Pagal tai apskričiai ir apylinkėms buvo paskiriamos šauktinių kvotos. Apylinkès šauktiniu skaičius buvo nustatomas aritmetiniu būdu, susumavus paskirų bendruomenių šauktinius. Šis, Karo prievolès statute gana apgaulingo pavadinimo, bendrasis apylinkès šauktinių sąrašas (obščij učastkovij spisok) taip pat tèra tik atskiru bendruomeniu sąrašu rinkinys, o ne nauja jų kompiliacija. Toks jis išlikdavo iki pat šaukimo. Tai matyti iš to,

${ }^{41}$ Vilniaus žydų bendruomenès deputatų 18740630 raportas. LVIA, F.937. Ap2. B.3639, L.607. 
kad šaukimo metu bendruomeniu atstovai visu pirma burtais nustatydavo bendruomenių seką, prieš traukiant pagrindinius burtus kiekvienam šauktiniui individualiai.

Lietuvos teritorija kaip ir visa carine imperija buvo suskirstyta $\mathfrak{i}$ karo prievolès atlikimo arba karinio šaukimo apylinkes (prizivnoj učastok). Jų teritorijas pagal savo kompetenciją nustatydavo gubernatoriai. Visų apylinkių sąrašas buvo išspausdintas St.Peterburgo „Pravitelstvenij vestnik", o gubernijų mastu atitinkamai „Gubernkije vedomosti". Kauno gubernijoje viena tokia apylinkè apėmè nuo 4 iki 10 valsčių. Valsčiai nebuvo skaldomi. Pavyzdžiui, i Kauno apskrities I šaukimo apylinkès sąrašą buvo sujungiami Kauno miesto, Vilijampolès, Rumšiškių ir Užusalių (Aleksandrovsko) valsčių krikščionių ir žydų bendruomenių sąrašai. Kauno apskrityje iš viso buvo ikurtos trys apylinkès su centrais Kaune, Kèdainiuose ir Seredžiuje, o, tarkim, Šiaulių apskrityje - penkios apylinkès: Šiauliuose (be miesto apèmè ir Šiaulių, Gruzdžių, Lygumų valsčius), Joniškyje, Papilëje, Radviliškyje ir Šaukenuose ${ }^{42}$. Vilniaus apskrityje be atskiros Vilniaus miestietiškos apylinkès buvo dar trys apylinkès su centrais Šumske, Giedraičiuose, Maišiagaloje, o Trakų apskrityje - Trakuose, Žiežmariuose, Stakliškèse ir Merkinejeje. ${ }^{43}$.

Šaukimo apylinkès, kuri neturejjo savo biurokratinio aparato, nereikia painioti su karo prievolès įstaiga. Apskritis i apylinkes buvo padalinta grynai pragmatiniais sumetimais - sutrumpinti šauktiniams kelionę iki šaukimo punkto ir sumažinti žmonių antplūdị šaukimo metu. Tokia apylinkė tik kelias savaites metu pabaigoje veikdavo kaip šauktinių surinkimo traukti burtu vieta. Apskrities karo prievolès valdininkai būdavo paeiliui komandiruojami keliuose punktuose organizuoti šaukimo. Pavyzdžiui, Kauno apskrityje šaukimo punktai būdavo atidaryti: Kèdainiuose - lapkričio 1-10 d., Kauno mieste - lapkričio 1-21 d., Seredžiuje lapkričio 22 - gruodžio 1 dieną". Visa raštvedybos medžiaga, suplaukusi iš šauktinių surinkimo punktu, vis tiek buvo organizuojama apskrities lygio įstaigose. Bet jų archyviniuose fonduose nepavyko aptikti nieko,

${ }^{42}$ Kauno gubernatoriaus 18740212 raštas Kauno miesto dūmai. KAA, F.61. Ap.2. B.5337,

L.2-3.

${ }^{43}$ Vilniaus apskrities policijos viršininko 18741122 raportas. LVIA, F.380. Ap.31.B.69, L.3960 .

${ }^{44}$ Kauno apskrities karo prievolès ịstaigos skelbimas. KAA, F.61. Ap.2. B.5337, L.235. 
kas paněšètu i apylinkès bendraji šauktinių sąrašą. Yra minimos tik kvotos. 1875 metais Vilniaus gubernijai Valstybès Senatas paskyrè 2329 šauktinių, o Vilniaus miestui 196 šauktinių kvotai Kvotos turèjo būti prieš šaukimą iš anksto publikuojamos "Gubernijos žiniose". Kaip 1874 metais buvo iprasta, apylinkiu šauktinių rinkinio sudarymas taip pat vẻlavo. Liepos pabaigoje Vilniaus miesto karinès prievolès įstaiga dar nežinojo savo apylinkès šauktinių skaičiaus ${ }^{46}$.

\section{Naujokų atranka}

Kaip jau buvo minèta, šauktinio anketos klausimynas yra padalintas i dvi dalis. Deja, archyviniuose karo prievolès istaigu fonduose veik be išimties šauktinių sąrašai susideda tik iš anketos pirmuju daliu. Šie sąrašai greičiausiai tèra neužbaigti dublikatai, o iki galo užbaigtu šauktinių sąrašu žinybinių keliu nepavyko nustatyti. Tačiau šauktiniu sąrašus sèkmingai pakeičia taip vadinami burtų sąrašai (žerebjovij spisok) ir naujokų priẻmimo sąrašai (prijomnaja rospis), turintys ne mažesnę išliekamaja vertę.

Šauktiniu vèlyvo rudens susirinkimas į šaukimo apylinkių punktus - iki to laiko absoliučiai daugumai naujokų sukakdavo 21-eri metai deklaruotas kaip savanoriškas žingsnis vardan „sosto ir tèvynės". Ką manė Lietuvos šauktiniai apie pareigą caro sostui ir jo „tèvynei" atskleidžia ju „balsavimas kojomis". Neatvykusiu i Vilniaus miesto karo prievolès istaigą traukti burtu 1874 metu šauktiniu sąrašas buvo išspausdintas atskira brošiūra ir išsiuntinètas imperijos europinès dalies policmeisteriams ${ }^{\wedge}$. Carinè valdžia griebėsi išbandytų ant rekrūtų kailio priemonių. Valsčiu viršaičiai buvo ipareigoti prižiūreti, kad šauktiniai susirinktų laiku ir kad būtų tvarka šaukimu punktuose ${ }^{48}$. Visgi susirinkus šauktiniams būta nemažo šurmulio juolab kad šaukimas truko 10 ir daugiau dienų.

\footnotetext{
45 Vilniaus gubernatoriaus 18750925 aplinkraštis. LVIA, F.499. Ap.1. B.1, L.250.

${ }^{46}$ Min. raportas, LVIA, F.380. Ap.31. B.69.

47 Vilniaus gubernatoriaus pranešimas. LVIA, F.499. Ap.1. B.8, L.5.

${ }^{48}$ Vidaus reikalų ministro 19741002 aplinkraštis \#91. LVIA, F.498. Ap.1. B.2,L191.
} 
Pirmiausiai apskričiu ir Vilniaus miesto komisijose būdavo nustatomas amžius pagal išorini subrendimą tų šauktinių, kurių amžiaus nepavyko nustatyti pagal dokumentus dar pavasari. Ivardintieji kaip tinkamo amžiaus papildè savo bendruomenių pagrindinius šauktinių sąrašus. Gubernijų lygio karo prievolès komisijos veikè kaip pirmujų sprendimų apeliacinès i̇staigos. Skundų netrūko. Oficialūs raportai nutyli atmosfera, tvyrojusią šaukimo punktuose nedideliuose bažnytkaimiuose, kur susirinkdavo iki tūkstančio jaunų vyrų. Vargu ar būdavo randama patalpa šiai miniai sutalpinti. O suvaldyti? Pagal statuto nuostatus prieš traukiant burtus galutinis šauktinių sąrašas turèjo būti perskaitomas girdint visiems šauktiniams, paminint pretenduojančius i lengvatas. Kiekvienas iš susirinkusių turejo teisę apskųsti tokius pretendentus. Reikia manyti, kad emocijų netrūko, nes ir burtų traukimas užtrukdavo kelias dienas.

Rusijos imperijoje burtai - tarsi atsitiktinis atrankos principas pradètas taikyti nuo 1854 metų. Tuomet eilę rekrūtams imti pradèta sudaryti burtais iš trijų skirtingu pagal sudèti šeimų kategorijų^ ${ }^{\wedge}$. Nuo 1874 metuc burtai tapo tikrai esmine karo prievolès sistemos kategorija. Būtent jie bent dalinai leido igyvendinti karinès reformos deklaruota viršluomini principa. Tik vadinamasis burtu sąrašas galų gale sulydydavo atskirus skirtingų luomų ir bendruomenių sąrašus į vieną bendrą šauktinių sąraša.

Burtas - tai šauktinio (jo giminaičio ar už ji komisijos nario) ištrauktas numeruotas lapelis. Šie burtų numeriai nustatydavo burtu sąrašą kitaip sakant eilę pagal kurią šauktiniai eidavo i medicininę ir karo prievolès i̇staigos bendrą komisija.

Eilè traukti burtus taip pat buvo nustatoma burtais. Tai yra skirtingų bendruomenių šauktiniai nesimaišydavo - tik pabaigus traukti burtus vienos bendruomenès šauktiniams, juos pradedavo traukti kitos bendruomenès nariai. Kadangi paprastai naujokų kvota maždaug per pusę būdavo mažesnè už apylinkès šauktinių skaičių, bendros eilès pabaigoje atsidūrę šauktiniai galèjo tikètis nepakliūti i kariuomenę. Viskas priklausè nuo šauktinių, turinčių lengvatas, skaičiaus. Jei burtų sąrašas sujungdavo skirtingų bendruomeniu šauktinius i bendrą sąrašą. Dar kartą ši bendrą sąrašą suskirsčius i 4 dalis pagal šauktinių šeimynines lengvatas buvo gaunama vadinamoji burtų knyga. Joje buvo iš esmės tie patys

Sovietskaja istoričeskaja enciklopedija.T.3 
šauktinio duomenys kaip ir burtu sąraše: pavardè, vardas, tèvavardis, ištrauktas burto numeris ir t.t.

I apžiūrą $\mathfrak{i}$ medicinos ir karo prievolès įstaigos narių bendrą komisiją iš pradžių buvo kviečiami šauktiniai, neturintys teisès i šeimynines lengvatas. Jei šios grupès šauktinių neužtekdavo, atitinkamai buvo kviečiami šauktiniai, turintys III (šauktinis, kurio pirmas iš eilès vyresnis brolis buvo pašauktas ir tarnauja kariuomeneje arba joje žuvo), po to II (šauktinis, kurio šeimoje yra vienintelis darbingas vyras - jo tèvas, išlaikantis jaunesnius nei 18 metu brolius) kategorijos šeimynines lengvatas. Šauktiniai, turintys I kategorijos lengvatą (vieninteliai šeimos maitintojai) i kariuomenę galèjo būti paimti tik Karo ministro ísakymu ${ }^{50}$. Burtu knygoje duomenu apie šauktinių šeimos narius nèra, bet žinant nuostatas lengvatoms gauti galima apytikriai spręsti apie šauktinio šeimos sudèti, net ir neturint kitu karinès prievolès sąrašų. Taip pat burtų knygoje buvo pažymimi šauktiniai, irašyti i atsargą, todèl tai kartu ir rezervistų sąrašas.

Kariuomenès naujokų sąrašas yra paskutinis iš karo prievolès sąrašų. Jame matomi galutiniai karo prievolès sistemos ir visuomenès dažnai priešingu pastangų rezultatai. Naujoku sąrašo klausimynas platus: naujoko asmens tapatybès duomenys, jo luomas ir ūgis, nuorodos i vedusių naujokų vaikus ir žmona, išpažistamas tikejjimas ir raštingumo lygis. Taip pat yra nuorodų $\mathfrak{i}$ šauktinio eilès numerius kituose karo prievolès sistemos sąrašuose, kur galima rasti kitas žinias. Vilniaus miestietiškos apylinkès 1877 metų sąraše yra irašyti iš viso 142 naujokai". Absoliuti ju dauguma i sąrašą buvo irašyta pirmą lapkričio savaitę. Po to lapkričio mènesi kasdien, o gruodi kas dvi trys dienos buvo įrašoma po vieną du naujokus. Irašymo į naujokus ir tikroji išsiuntimo į veikiančią kariuomenę data nesutampa. Po priesaikos čia pat šaukimo punkte vyrai, pripažinti naujokais, galëjo būti dar paleidžiami namo, kaip buvo numatyta Karo prievolès statute. Paprastai i pulkus jie buvo išsiunčiami jau kitu metu sausio mėnesi. Todèl tituliniai naujokų sąrašo metai nebūtinai atitinka ju realios karinès tarnybos pradžią. Keliolika naujoku i sąlygini 1877 metu sąrašą buvo įrašyti 1878 ir net 1879 metais. Paskutinis 1877 metu sąrašo naujokas i ji pakliuvo 1879 rugséjo ménesi. Taip yra todèl, kad dalis nau-

\footnotetext{
${ }^{50}$ Karo prievolès statuto punktas \#45

${ }^{51}$ Kariuomenès naujokų sąrašas, LVIA F.499. Ap.1.B.1322.
} 
jokų dèl įvairiu priežasčiu buvo atleisti nuo tarnybos jau po įrašymo i naujokų sąrašą ar net pradejję tarnybą. Vèliau paimti į tarnybą naujokai buvo atitinkamai metais ar dviem vyresni. Pagal luomus 1877 metu Vilniaus miestietiškos apylinkès naujokai pasiskirstè taip: 12 bajorų ir 130 miestiečiu (kitu luomų - garbès piliečiuc, pirkliu, karininkų sūnų - nebuE vo). Absoliuti dauguma miestiečių buvo Vilniaus miestiečiai, bet kadangi šiai karinei apylinkei priklause ir Vilniaus apskrities žydų bendruomenès, todèl į sąrašą pakliuvo: 7 žydai iš Antakalnio, 2 - iš Šnipiškių ir po vieną iš kitų bendruomeniu.

Carinès Rusijos karo prievolès sistemos kritika neišvengiamai yra ir jos šaltiniu kritika. Vienokia ar kitokia informacija apie šeimos sudeti buvo nuolat perrašoma iš vieno karinès prievolès sistemos sąrašo i kitą. Žinoma, jų darbą kontroliavo miestų dūmos, valsčių valdybos, karinès prievolès komisijos, bet principo tai nekeičia. Karo prievolès raštvedyba rodo, kad vyko arši kova tarp valstybės aparato ir karo prievolininku šeimų dèl lengvatų pripažinimo. Net iki 50 nuošimčiu visų šauktinių buvo atleidžiama nuo karinès tarnybos pagal šeimynines lengvatas ${ }^{52}$. Lengvatos buvo priskiriamos dar pačioje pirmoje biurokratineje grandyje kai bendruomenių deputatai pilde šauktinių anketas, nurašydami duomenis iš revizinių ar šeimų sąrašų. Žinant, kad daugumos Lietuvos gyventojų akyse caro valdžia moralinès sankcijos neturejo (užtenka prisiminti sukilimus), galima numanyti, kad tautų kalëjimo imperijoje atsirado nemažai žmonių, pasiryžusių pataisyti abejingą demografiją „kultūrinėmis" priemonėmis, pasinaudojant carinès biurokratijos brūzgynais. Pripažintos ar nepripažintos, bet egzistavo visuomeninès normos, neigiančios atsitiktinumą ir paverčiančios ji nerašytomis taisyklëmis. Atsitiktinis burtas negalëjo tapti teisès norma aneksuotoje ir jèga valdomoje šalyje. Istoriografijoje dažnai minima, kad Lietuvoje rekrūtai buvo ,gaudomi", bet neretai už to slypejjo tos pačios bendruomenès aukštesnio socialinio statuso narių atsipirkimas nuo rekrūtu prievolès. Pagaliau egzistavo oficialiai iteisintas būdas išsipirkti nuo rekrūtu prievolès. Už išpirką 1874 metais (rekrūtai buvo imami iki 1874 metų vasario mėnesio) reikèjo mokèti 485 rublius sidabru ${ }^{53}$. Burtų ivedimas privertè visuomenę tas normas pertvarkyti, bet jų nepanaikino, ar tai būtų emigracija į užsienį ar valdininkų papirkimas.

\footnotetext{
${ }^{52}$ Zajončkovskij P.A. Samoderžavije i ruskaja armija na rubeže 19-20 stoletij. Maskva, 1973, L. 215 .

${ }^{53}$ Rekrūtų ỉskaitinių kvitų išpirkimo taisyklès. LVIA, F.498. Ap.1. B.2, L.45.
} 
Jei pasitikèti straipsnio pradžioje minètu V. Steponaičiu, Rusijos imperijos karo reforma Lietuvoje iš esmès žlugo.

Lietuvos aneksija ị Rusijos karo prievolès sistemą pasibaigè 1915 metais Lietuvą okupavus kaizeriniai Vokietijai. Bet ir evakuotos i Rusijos gilumą carinès institucijos dar kelis metus bandè sudarinèti šauktiniu iš „Šiaurès Vakaru krašto" sąrašus. Lietuviai tarnavę Rusijos kariuomenèje po Vasario revoliucijos pradèjo organizuotis i lietuviu pulkus. Tai yra, sieke itteisinti tą statusą, kokị seniai turèjo suomių šauktiniai. Rusijos karo prievolès sąrašai lieka daugiau Lietuvos kultūros nei politikos istorijos šaltiniai.

\section{Résumé}

Listes et documents non répertoriés du service militaire de la Russie tsariste en Lituanie, Vilius Botyrius

Bien que suite q la réforme du service militaire de la Russie impériale le service militaire a été réduit de 2037 ans, les autorités exigeaient tout de mime de la Lituanie un nombre bien plus grand d'appelés qu'ils en exigeaient auparavant de recrues. Désormais la moitié des hommes âgés de 20 ans devaient servir dans les rangs d'une armée étrangère et le service militaire devint générale et concerna toutes les couches de la société, autant les paysans et les citadins non privilégiés que les nobles. A cause de cette réforme générale il a fallu créer un système totalement nouveau de recensement des appelés et de toute la population lituanienne. De 18743 1876, le pouvoir russe mil en "uvre quelques actions que Ton peut considérer comme le troisième recensement de la population par son importance, ayant eu lieu après ceux de 1790 et 1897 . Lors de cette étape les toutes premières listes familiales ont été établies, les recensements précédents ont été complétés et les appelés juifs recensés. La deuxième étape de cette réforme qui dura jusqu'en 1915 est l'inscription des jeunes soldats dans les registres des cantons (kniga dla zapisi pripisannych k prizivnym ucaslkam) sur les listes annuelles d'appelés (caslnije prizivnije spiski) et sur les listes des conscrits (priemnaja ropsis). I.es dénominations de ces sources de décompte de la population ne reflètent pas tout leur contenu. Grâce a. ces documents il était possible de connaître les données personnelles con- 
cernant l'appelé, sa couche sociale, sa date de naissance, sa confession, son niveau d'éducation, son occupation ou son activité commerciale, son lieu de résidence ainsi que des renseignements concernant sa famille. Une partie de ses documents est conservée dans les archives historiques du gouvernement lituanien, dans celles du district de Kaunas ainsi qu'en Russie. Un grand nombre d'entre elles ont été détruites.

Bien que le service militaire soit devenu général, des institutions différentes ont été chargées de l'organiser selon le principe des classes. Une partie des listes était établie dans les institutions du service militaire nouvellement créées dans chaque région. Ijes anciennes institutions des classes comme le conseil de la ville ou le conseil des districts étaient chargées d'établir les autres listes, bien qu'en fait ce travail était fait par les représentants des communautés religieuses territoriales tant juives que chrétiennes délégués 3 la mairie. La non concordance entre les destinataires de la réforme du service militaire et les institutions des classes, qui devait mettre la réforme sur pied, fut l'obstacle principal de cette réforme libérale en soi. En raison du recensement de la population l'établissement des listes des appelés obligatoires prit beaucoup de retard et connut de nombreuses difficultés, surtout pendant les premicres années. Il a fallu organiser un nouveau système de répartition des conscrits étant donnée que la moitié des appelés selon leur classe d'âge suffisait pour remplir les rangs de l'armée. D'un premier abord, il pourrait sembler que le point culminant du système de répartition et de tout l'appel est le tirage au sort : qui sera dans les rangs, qui sera réserviste ? Toutefois en ayant étudié le sujet de plus pres, on constate que la répartition des conscrits s'est faite principalement dans la jungle de la bureaucratie russe. Etant donné les règles contradictoires d'exemption de service pour les appelés ainsi qu'une organisation peu fiable et a plusieurs niveaux du recensement des données démographiques, la place de l'appelé désignée par le fonctionnaire était bien plus décisive que n'importe décision prise en tirant au sort. Le problème le plus difficile $£ j$ résoudre était la détermination de l'âge, chose impensable dans notre société bureaucratique actuelle. Seul l'ordre dans lequel les appelés bénéficiant des mzmes conditions d'exemption étaient choisis, relevait d'un tirage au sort. Seuls les bénéficiaires d'exemption se retrouvaient en fin de liste et pouvaient de cette manière espérer échapper au service militaire. Les appelés étaient répartis en quatre catégories d'exemption, dépendant de leur situation familiale. Les appelés ne bénéficiant d'au- 
cune exemption ne suffisaient pas pour remplir les rangs de l'armée. A leur suite, les appelés bénéficiant des catégories d'exemption III, II, I devaient passer devant la commission de répartition des conscrits. Les catégories d'exemption étaient les suivantes :

catégorie III : appelé dont le premier frère aîné a déjà été appelé, sert dans l'armée ou est mort pendant son service ;

catégorie II : appelé, dont le seul homme capable de travailler dans la famille est le pere et ayant a charge des enfants de moins de 18 ans ;

catégorie I : l'appelé est le seul 3 subvenir aux besoins de la famille, ils pouvaient ztre appelés seulement sur ordre du ministre de la Guerre.

La majorité des Lituaniens étaient loin de vouloir servir dans l'armée impériale. Comme le pouvoir tsariste ne reconnaissait pas les objections de conscience, ils essayaient tant bien que possible d'échapper au service militaire. «Leur vote par les pieds» prouvaient ce que pensaient les appelés lituaniens du devoir de servir le tsar et leur patrie. La liste des appelés devant tirer leur ordre au sort ne s'étant pas présentés au bureau du service militaire de Vilnius en 1874 a été imprimée sur une brochure a part et envoyée dans tout l'empire. En 1875 , ce sonl 2329 appelés qui étaient attribués au gouvernement de Vilnius et 1963 la ville de Vilnius. Les Juifs était la couche de la société la plus mobile, et donc la plus difficilement contrôlable, mzme sous menace de fortes amendes. Les Lituaniens qui Font pu, ont choisi l'émigration illégale, le plus souvent vers les Etats-Unis d'Amérique. Qui étaient-ils ces appelés lituaniens, des victimes passives ou des héros de l'exode de la nation lituanienne?

Dans l'armée russe, les Lituaniens ne se sont pas regroupés en fraction nationale, comme par exemple les Finlandais. Pour cette raison peut-ztre l'histoire des appelés lituaniens n'est pas encore écrite. 